\title{
ACCOUNTING PRINCIPLES AND INVESTMENT ANALYSIS
}

\author{
Douglas A. Hayes
}

In a broad sense, there are three major technical problems that surround the use of accounting data in investment analysis. The first is the reliability of the data within a given reporting period as an indication of the actual economic results pertaining to the period and of the financial position of the enterprise at the terminal date. The second is the problem of consistency in the determination of revenues, expenses, and the related asset values through time within a given corporate enterprise. The third is that of the comparability of the data offered by several similar firms within the same general industry area.

The accounting techniques that may distort or obscure actual economic results and financial position are probably of most importance to the nonprofessional investor since, for the most part, professional analysts can make the necessary adjustments from a penetrating appraisal of the statements and the notes appended thereto. Nonprofessionals, however, not trained to understand and interpret the significance of particular items, may find these adjustments beyond their competence.

The Importance of Consistency in the Application of "Principles"

From the viewpoint of the professional analyst, a case can be made that the validity of the accounting principles applied during any given period to the determination of income and financial position are less important than consistency of application through time and their comparability within a given industry area. The reason is that a major objective of many investment analysis techniques is to obtain an insight into the probable pattern of future corporate performances and the relative performances of several firms within the industry group. For example, there is the very important question in investment appraisals of estimating the comparative rates of growth in earning power of different companies. In addition, the estimated range of fluctuations as a consequence of changing economic or industry conditions is of considerable significance.

If inconsistencies in accounting procedures produce arbitrary distortions in the pattern of reported earnings through time, the task of the investment analyst becomes considerably more difficult. Not only must the analyst reach decisions on the

- A.B. 1939, M.B.A. I940, Ph.D. 1950, University of Michigan. Professor of Finance, Graduate School of Business, University of Michigan; Council of Examiners, Chartered Financial Analysts, 1962.64; Chartered Financial Analyst, I965; formerly with Price, Waterhouse \& Co., and Investment Counsel, Inc. (Detroit). Author, Investments: Analysis and Management (I961); Banx Lending Policies: Issurs AND Practices (I964). Contributor of articles to business and financial periodicals. 
substantive economic issues, such as the probable growth in the demand for the products and prospective competitive conditions, but in addition it becomes necessary to ascertain the real quantitative impact of past developments in these matters via eliminating the effects of changes in earnings produced solely by variations in accounting techniques. As a result, the more penetrating treatises on investment analysis feel obliged to devote several chapters to the principal problem areas involved, to the means of eliminating the effects of accounting inconsistencies from the reported results, and to making comparable the reported results of two or more firms in the same general industry area. ${ }^{1}$

In some instances, it must be admitted, there may be a conflict between the desire for consistency in the application of accounting principles and the desire for obtaining the most accurate absolute portrayal of results for a given period in the light of emerging experience. It is an unfortunate fact that the incidence of important costs can only be roughly estimated at a given time, and future experience may indicate that serious errors were made in the estimation process. The annual accruals of depreciation expenses on plant assets and of the appropriate costs incident to the funding of pension programs are perhaps the major culprits on this score. If developments through time indicate that these costs have been estimated on the basis of projected data which experience now indicates to be in error, then corrections in the interest of "truth" in setting forth the current results would seem entirely justified.

It would be difficult indeed to argue with this proposition as stated. However, in many cases the revealed "truth" would also suggest the complete restatement of the past earnings reports for perhaps a decade or more. But conventional accounting practices usually extend only to the correction of the current year, or possibly one preceding year, and not to the complete series of past reports which theoretically would be affected by the new knowledge. The extensive effort involved in such restatements plus the belief that results for previous years are of only academic interest may be responsible for prevailing practice. However, when substantive corrections in the basis for major expense determinations have been made and the retroactive effects are ignored, then the comparability of the accounting data through time might be seriously impaired for investment analysis purposes. For example, the computation of meaningful long-term growth rates from such data may become exceedingly difficult if not impossible.

In connection with the above problem, the question might legitimately be raised as to whether the public accounting firms should not be charged with the duty to require restatement of the financial statements of prior years when experience suggests the need to revise the basis for the determination of significant expense items. The argument for raising the question would rest in the language of the

\footnotetext{
${ }^{1}$ See, e.g., Douglas A. Hayes, Investments: Analysis and Management 196-24I (I96I); Benjamin Grayam, Dayid L. Dodd \& Sidney Cottle, Security Analysis i2i-7o (4th ed. 1962).
} 
conventional auditor's report pursuant to an unqualified opinion on the financial statements. Typically such a report includes the following language:

In our opinion, the accompanying consolidated balance sheet and consolidated statements of income and retained earnings present fairly the financial position of the Company as of [date] and the results of its operations for the year then ended, in conformity with generally accepted accounting principles applied on a basis consistent with that of the preceding year. [Emphasis added.]

Such language would seem to justify the supposition, for example, that if the percentage rates at which existing depreciable assets are charged off are changed, then the new rates would be retroactively applied to determine the depreciation expense of prior years to reflect the conditions that presumably induced the deviation in the write-off period. If the retroactive adjustments were not made, the language to the effect that accounting principles have been consistently applied through time hardly appears justified.

However, a convenient distinction has been developed in the accounting profession to distinguish between accounting principles and accounting procedures. Principles apparently are considered to be limited to the broad policy concepts related to the preparation of the financial statements; as an example take the idea that cost should be the primary measure of value of depreciable assets and that in some fashion the cost should be allocated against the revenue stream over the useful life of the assets. The example mentioned is generally regarded as the "cost principle." But the means used to implement this principle have been relegated to the status of procedures. ${ }^{2}$ Therefore, if the estimates of useful life on given depreciable assets are changed due to new information, it is argued that retroactive adjustments are not required because there has merely been a change in procedure and not in the principle that an amortization of cost over the useful life should govern the write-off period.

Therefore, the fact that a company may radically revise its methods for determining depreciation rates, such as a change from a straight-line method to an accelerated method, is not considered to be a deviation from the consistent application of accounting principles. Moreover, under existing conditions in accounting practice, alternative procedures yielding widely different cost allocations in given years may be applied to identical assets by different firms, and all may receive an unqualified auditor's opinion that their statements have been prepared in conformity with generally accepted accounting principles. ${ }^{3}$

The semantic arguments that have been advanced in order to define and restrict the province of accounting "principles" as contrasted to that of "procedures" or "methods" seem strained and contrived for a presumably highly practical profession.

\footnotetext{
${ }^{2}$ Kemp, Controversies on the Construction of Financial Statements, 38 Accounring Rev. 126, 128.29 (1963).

${ }^{8} I d$. at $\mathrm{r} 29$.
} 
As so defined and restricted, "principles" per se are not likely to raise problems of consequence to investment analysis. Therefore, for purposes of the subsequent discussion, a broader definition of accounting "principles" will be employed to include many of the problems of consistency and comparability that in a literal definitional sense may arise from differences in "procedures" or "methods."

\section{II}

Income Determination: Conflict in Accounting Principles

The investment analyst is concerned only with an evaluation of the future return opportunities and risks within a given enterprise. Therefore, accounting data are useful only to the extent they provide clues to these opportunities and risks. As a consequence, it would be desirable for the income statements to reflect only that flow of revenues, costs, and related income that seems pertinent to future operations. Similarly, the balance sheet would be stated in a form to reflect clearly the financial obligations of the firm, the nature of the assets, and the equity of the shareholders. Then, as brought out above, from a series of such statements it is anticipated that an insight into the potential trends and fluctuations of these items can be obtained.

As a consequence of these objectives of investment analysis, it would follow that (I) transactions involving gains and losses to the firm that are unusual or nonrecurring in nature should be excluded from reported income and (2) all financial commitments related to future operations would be clearly presented in the balance sheet. Some generally accepted accounting principles, however, do not necessarily reflect these views on the preparation of financial statements.

With respect to the first concept, considerable controversy has existed within the accounting profession between those advocating the "all-inclusive" concept of net income and those advocating the "current operating performance" concept. ${ }^{4}$ Proponents of the "all-inclusive" concept take the position that all items that increase or decrease the equity of the owners in the business, except dividend distributions and capital stock transactions, should be included in net income. In contrast, the "current operating performance" view is that net income should reflect only that flow of income incident to the actual operating conditions of the period. ${ }^{5}$

Clearly, it is the latter view that would be preferable for investment analysis purposes. However, the research committee of the American Institute of Certified Public Accountants unfortunately takes an equivocal position on the matter. It is first held that there should be a general presumption that all items of profit and loss recognized during a period should be included in determining net income; then

\footnotetext{
t The terms are in current usage within the accounting profession. E.g., Committe on Accounting Procedure, AicPa, Restatement and Revision of Accounting Research Bulletins 6o (Accounting Research Bull. No. 43, 1953 ).

"For the detailed arguments advanced for each of these views, see id. at $60-62$.
} 
TABLE $\mathrm{I}$

Cowles Magazines and Broadcasting Inc.

Condensed Income and Surplus Statements

(in thousands of $\$$ )

\begin{tabular}{|c|c|c|}
\hline & 1963 & 1064 \\
\hline 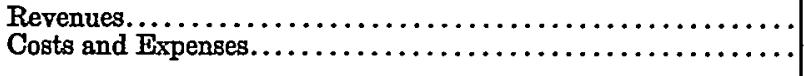 & $\begin{array}{r}\$ 128,065 \\
120,690\end{array}$ & $\begin{array}{r}\$ 133,302 \\
127,040\end{array}$ \\
\hline 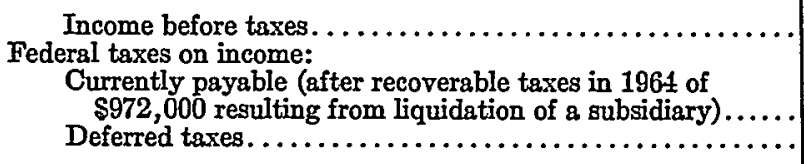 & $\begin{array}{r}\$ 7,375 \\
2,993 \\
897\end{array}$ & $\begin{array}{r}\$ 5,361 \\
741 \\
809\end{array}$ \\
\hline Net income for year.. & \& 3,485 & $\$ 3,811$ \\
\hline $\begin{array}{l}\text { Add: Earned surplus, beginning of year....................... } \\
\text { Deduct: } \\
\text { Appropriation for revaluation of investment in General } \\
\text { Development Corporation to approximate market....... } \\
\text { Deficit of Star Publishing Co. as of January } 1,1963 \ldots \ldots \ldots\end{array}$ & $\begin{array}{r}8,522 \\
694\end{array}$ & $\begin{array}{r}10,173 \\
2,384\end{array}$ \\
\hline Earned surplus, before dividends for year... & $\$ 11,313$ & $\$ 11,600$ \\
\hline
\end{tabular}

Source: Annual Report for 1964 .

it is stated that certain exceptions in the form of specified extraordinary items may be excluded; and finally it is stated that these items "should be excluded when their inclusion would impair the significance of net income so that misleading inferences might be drawn therefrom." Moreover, to the distress of financial analysts, the Securities and Exchange Commission has taken a similarly equivocal position. It originally supported the view that all items of gain or loss should be reflected in the income statement and then subsequently compromised this position by allowing (not requiring) special items to be reported after arriving at the "net income" figure.

The result of the indecisive posture of both the AICPA and the SEC has been a hodge-podge of treatment of special gains and losses both as between companies and within the same company. The SEC itself has made the damaging admission that its examination of reports to stockholders "reveals that some companies have a tendency to report favorable items in the income statement and unfavorable items as direct charges to earned surplus without adequate comment elsewhere."

Table one provides an illustration of an inconsistent treatment of special gain and loss items and of the problems for investment analysis that ensue. These data

\footnotetext{
Id. at 63 .

"See statement prepared by the office of the chief accountant, SEC, filed by the Commission with the Subcommittee on Commerce and Finance, House of Representatives, Feb. 19, 1964, J. Accountancy, June 1964, p. 56 , at $57-6 \mathrm{r}$.

${ }^{8} I d$. at 59 .
} 
show that the net income before federal taxes of Cowles Magazines and Broadcasting Inc. declined in $I 964$ from Ig 63 by more than $\$ 2$ million. But, paradoxically, reported net income after taxes actually increased by $\$ 326,000$ in 1964 from 1963 levels because of a decrease in the provision for income taxes of $\$ 2.3$ million. While the corporate tax rate did decline modestly in $\mathrm{Ig} 64$, a considerable portion of the greatly reduced tax accrual $(\$ 972,000)$ was due to tax recovery resulting from the liquidation of a subsidiary. This item could clearly be labeled a special gain item as it might be legitimately supposed that liquidations of subsidiaries are not a recurring and normal element in the operations. Therefore, under the "current operating performance" concept of net income determination, the tax recovery would have been shown as a special addition to the statement subsequent to the determination of the "net income" figure.

Indeed, it can be noted that in 1964 the special loss item consequent to the revaluation of an investment in another corporation was in fact treated as a direct deduction from earned surplus rather than allowed to reduce reported net income. In short, it appeared that the "all-inclusive" concept of special items was applied to such gains while the "current operating performance" concept was applied to losses of a similar sort. Finally, it might be mentioned that despite the apparent inconsistency in the treatment of these items, the company's statements received the standard unqualified opinion from a leading public accounting firm.

As suggested earlier, the major social impact of the inconsistent, and indeed sometimes conflicting, accounting principles applied to special gains and losses bear on the relatively unsophisticated investor. As adequate disclosures are usually made, the trained professional can adjust reported net income for such items without great difficulty. However, nonprofessionals more than likely accept net income and related earnings per share without a critical examination of their composition. ${ }^{9}$ Moreover, it may be conjectured that many, if not most, nonprofessional investors find the terminology and explanations of these items more confusing than enlightening. Disclosure is useful; but if an intelligent interpretation of the disclosed items depends upon a thorough knowledge of the subtleties of accounting theory, the objectives of disclosure, i.e., to promote intelligent decision making, may be largely forfeited. In short, the position taken by the SEC as to its power over accounting matters under the Securities Act of $x 933,{ }^{10}$ that its role should be limited to requiring full disclosure of financial facts and that it should not regulate the form and method of disclosure, may be questioned if protection of the nonprofessional investor is considered to be among the SEC's primary social objectives.

\footnotetext{
'In the statistical investment services-Moody's Investors Service and Standard and Poor's Corporation Service-the earnings per share of Cowles Magazine and Broadcasting Inc. were reported as $\$ \mathrm{r}$.I7 for 1963 and $\$ 1.28$ for 1964 without comment. It might be presumed that the data presented in these services are widely used by nonprofessionals.

${ }^{10}$ Section $\mathrm{r}_{9}(\mathrm{a}), 48$ Stat. 85 , as amended, ${ }_{5}$ U.S.C. $\$ 77 \mathrm{~s}(\mathrm{a})(\mathrm{rg} 64)$.
} 


\section{III}

\section{Income Determination: Recognition of Subsidiary Earnings}

For legal, tax, or other reasons the modern corporate complex often includes a number of separate legal entities that typically operate as an integral group in the production and distribution of the product line. Under these conditions the investor in the parent company is primarily interested in the earning potential and financial soundness of the entire economic entity rather than in any particular legal component. The general view in investment analysis is that the composite earnings and obligations more appropriately measure the investment opportunities and risks within the enterprise. The only major exception would be where the security being evaluated occupies a creditor position against subsidiary operations without the guarantee of the parent. Such securities, however, are rarely found in the securities markets today.

By and large, generally accepted accounting principles agree with this view. ${ }^{11}$ However, two difficulties arise in implementing the general principle. First, it is held that consolidation should take place only when there is "a controlling financial interest," which in turn is defined as ownership of more than fifty per cent of the voting shares. ${ }^{12}$ Second, on the ground that currency conversions may be restricted and devaluation risks may be great, the implementation recommendations are only permissive with respect to foreign subsidiaries. ${ }^{13}$ It is notable that the bulletin with respect to foreign subsidiaries originally appeared in late 1939 when restrictions on the convertibility of currencies were widespread and the hostilities in Europe had begun. In view of the subsequent balance of payments difficulties of this country, the argument now appears considerably less persuasive if not obsolete; yet no evidence can be found that the 1939 statement on the recognition of foreign subsidiary earnings has been modified. Indeed, it was reiterated in the I953 restatement of the Research Bulletins in essentially the same language. ${ }^{14}$

The view that more than fifty per cent ownership should be the normal prerequisite to consolidation seems unduly rigid for investment analysis purposes. While this rule is perhaps in accord with literal legal theory, control can in fact be exercised and the operations essentially integrated with the parent company when fifty per cent or less of the voting stock is held, especially if a significant segment of the balance is held by friendly parties. When consolidation of affliates (the usual

\footnotetext{
II The Committee on Accounting Procedure, AICPA, has gone on record as follows: "There is a presumption that consolidated statements are more meaningful than separate statements and that they are usually necessary for a fair presentation when one of the companies in the group directly or indirectly has a controlling financial interest in the other companies." Commutree on Accounting Procedune, AiCpa, Consolidated Financial Statements 4I (Acccounting Research Bull. No. 51, 1959).

${ }^{12}$ Ibid.

${ }^{23}$ Committee on Accounting Procedure, Aicpa, Foreign Operations and Foreign Exchange 29-3I (Accounting Research Bull. No. 4, I939).

14 Committee on Accounting Procedure, AicPa, Restatement and Revision of Accountino Research Bulletins ir2 (Accounting Research Bull. No. 43, 1953).
} 
term for companies actually controlled) is not effected, then the earnings of the parent company will include only dividends actually paid by the affliates to the parent although supplementary disclosure of the parent's equity in the total earnings of such affiliates has been held desirable. Because the parent company may vary the proportion of affliate earnings distributed in the form of dividends, the actual earnings performance of the entire corporate group, which is of primary concern to investors, may be significantly different than reported.

An example might be useful to clarify this important point. Table two shows the reported earnings for Kimberly-Clark Corporation, a leading producer of tissue and book papers, for the fiscal years $196 \mathrm{r}-64$. These earnings, however, reflected only the actual amounts of dividends received from several Canadian affiliates that produce wood pulp and other raw materials mainly for the parent company. Therefore, the table also indicates the earnings that would have been reported had a full consolidation been effected of the affiliates' earnings, which would seem reasonable in view of the close operating relationships. While the differences between dividends received from these affiliates and the equity of Kimberly-Clark in their total earnings were not substantial in any given year, the fact that dividends received were less than such earnings in I96r and greater in I964 had a significant impact on the indicated growth rate. As reported, the company showed a growth in earnings of 14.2 per cent from Ig6I through I964, but, when earnings were adjusted for differences in the proportion of affiliates' earnings declared as dividends, the earnings growth was only 9.4 per cent. As the growth rate factor is a very important element in investment appraisals, it could be argued that reported earnings significantly distorted important data for investment decision purposes.

TABLE 2

Kimberly-Clark Corporation

Adjustment for Earnings of Affliates

(in millions of \$)

\begin{tabular}{|c|c|c|c|c|c|}
\hline \multirow[b]{3}{*}{$\begin{array}{l}\text { Affiliate dividends to parent............... } \\
\text { Equity in earnings of affiliates............ }\end{array}$} & \multicolumn{4}{|c|}{ Fiscal years ended April 30: } & \multirow{2}{*}{$\begin{array}{l}\text { \% Increase } \\
1961-64\end{array}$} \\
\hline & 1961 & 1962 & 1963 & 1964 & \\
\hline & $\$ \frac{1.9}{2.1}$ & $\begin{array}{r}1.9 \\
.8\end{array}$ & $\$ 1.9$ & $\begin{array}{r}S 2.3 \\
1.1\end{array}$ & \\
\hline $\begin{array}{l}\text { Excess (deficiency) of earnings over } \\
\text { dividends......................... }\end{array}$ & .2 & (1.1) & $(.3)$ & (1.2) & \\
\hline 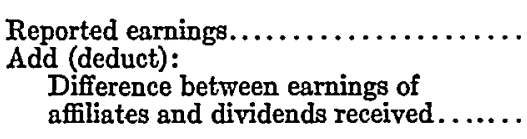 & $\$ 31.4$ & $\begin{array}{l}\$ 31.5 \\
(1.1)\end{array}$ & $\begin{array}{r}\$ 33.9 \\
(.3)\end{array}$ & $\begin{array}{l}\$ 35.8 \\
(1.2)\end{array}$ & $14.2 \%$ \\
\hline Adjusted earnings... & $\$ 31.6$ & $\$ 30.4$ & $\$ 33.6$ & $\$ 34.6$ & $9.4 \%$ \\
\hline
\end{tabular}

Source: Annual Reports for 1961-1964. 
It is true that adequate disclosures of the data necessary for the adjustments were made in footnotes to the several annual reports. But each year was considered separately for this purpose, and the facts for prior years were not reported in each of the current years. Therefore, even professional analysts, unless extremely careful in their analytical procedures, might have failed to discern the true pattern of the earnings performance, especially as the differences in any one year did not appear significant in amount. As a solution to the problem, it might be recommended that the current income statement and the financial summaries of prior years show clearly in some fashion the total earnings performance of the entire operating group including closely allied affiliates prepared along the lines of table two.

Turning ourselves to the question of foreign subsidiaries, the prevailing recognized practice that earnings derived from foreign operations can either be fully consolidated or alternatively recognized only to the extent of dividends remitted to the parent company creates analytical problems both as outlined above and also with respect to the comparability of companies within a given industry area. For example, in the office equipment industry, foreign operations are usually of considerable importance to most leading companies in the field. Yet as shown in table three, Burroughs Corporation follows the practice of fully consolidating its world-wide operations whereas National Cash Register Company makes a deduction on its income statement for net earnings of foreign subsidiaries and branches not remitted to the United States. As a result, legitimate comparisons of these companies' per-

TABLE $_{3}$

National Cash Register Company versus Burroughs Corporation

Treatment of Foreign Earnings (in millions of \$)

\begin{tabular}{|c|c|c|c|c|}
\hline & 1961 & 1962 & 1963 & 1964 \\
\hline $\begin{array}{l}\text { National Cash Register Co.: } \\
\text { Reported Net Income: } \\
\text { Foreign subsidiary dividends........ } \\
\text { Domestic and Canadian........... }\end{array}$ & $\begin{array}{r}\$ 10.0 \\
11.7\end{array}$ & $\begin{array}{r}S 8.7 \\
11.9\end{array}$ & $\begin{array}{r}\$ 10.8 \\
9.3\end{array}$ & $\begin{array}{r}\$ 10.5 \\
12.0\end{array}$ \\
\hline 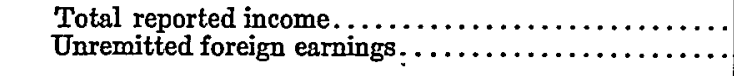 & $\begin{array}{r}\$ 21.7 \\
8.4\end{array}$ & $\begin{array}{r}\$ 20.6 \\
2.6\end{array}$ & $\begin{array}{r}\$ 20.1 \\
2.3\end{array}$ & $\begin{array}{r}\$ 22.5 \\
3.7\end{array}$ \\
\hline Total: full consolidation assumed.. & $\$ 30.1$ & $\$ 23.2$ & $\$ 22.4$ & $\$ 26.2$ \\
\hline 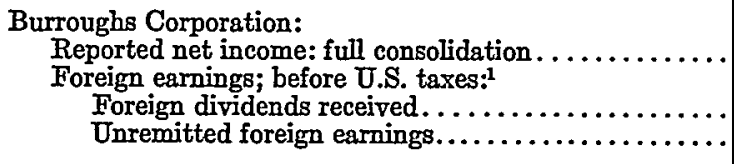 & $\begin{array}{r}\$ 10.5 \\
\$ 7.3 \\
3.9\end{array}$ & $\begin{array}{l}\$ 9.5 \\
\$ 4.4 \\
\mathbf{5 . 1}\end{array}$ & $\begin{array}{l}\$ 8.5 \\
\$ .2 \\
9.4\end{array}$ & $\begin{array}{l}\$ 10.2 \\
\$ 6.1 \\
5.0\end{array}$ \\
\hline Total. & $\$ 11.2$ & $\$ 9.5$ & $\$ 9.6$ & $\$ 12.0$ \\
\hline
\end{tabular}

1Computed from data provided in "Financial Review" section or footnotes to annual reports. Information not provided on income statements.

Source: Annual Reports for 1961-64. 
formances-as to rates of return obtained on investment and earnings trends, for example-would require the adding back of the unremitted foreign earnings to the reported net income of National Cash Register.

As the full consolidation method used by Burroughs has become the preferred practice in recent years, it is, therefore, paradoxical to note that the data supplied by National Cash Register offer more complete information on the important matter of the geographic sources of net income than do the data supplied by Burroughs. For example, in investment appraisals, the value ascribed to net income derived from foreign sources may be quite different than that attached to domestic earnings because of greater political and economic uncertainties abroad.

In the case of National Cash Register, the amounts of net income derived from each source after appropriate tax allocations were fully disclosed in the statements or footnotes thereto. However, neither in the body of its reports nor in the related discussion has Burroughs Corporation shown the proportion of after-tax net income derived from various sources. The amounts of foreign net earnings and gross dividends remitted were given in a "Financial Review" accompanying the income statement, but the U.S. income taxes payable on such dividends were not shown. As the income statement proper revealed net income only on a fully consolidated basis after all taxes, the proportion of net earnings derived from foreign sources could only be roughly estimated via making an assumption as to the amount of income taxes properly applied to foreign dividends. In short, for investment analysis purposes, effective comparability between companies with significant foreign operations would require that the principle of full consolidation be supplemented with disclosure as to the geographic sources of net income on some reasonable basis.

In order to make similar distinctions regarding the "quality" of earnings, a theoretically "ideal" income statement for investment analysis purposes would reveal the amounts of sales, expenses, and net income by major product lines. Wide diversification of product lines has become increasingly common through mergers and acquisitions in the postwar years. The Olin Mathieson Chemical Company complex of divisions and subsidiaries represents perhaps the extreme of such diversification, its products including chemicals, drugs, cement, metals, and firearms. As the growth and stability prospects for the several industry areas included in the product line may be quite different, an income statement showing the amounts of sales, and possibly earnings, derived from each would be quite helpful in an investment appraisal of such a company. But when requesting such information, the analyst is typically told that such breakdowns are not available for "competitive reasons." 15 As it has been alleged that competitors in one way or another often

\footnotetext{
${ }^{15}$ At a financial analysts meeting in Detroit a few years ago, the author pressed officials of the Ex-Cell-O Corporation for a breakdown in sales and profit margins by major product lines. The officials used "competitive reasons" as the grounds for refusing to disclose the information, and several practicing analysts stated that even in private interviews managements typically will give only very general intimations as to the relative importance of various product lines to sales and earnings.
} 
obtain much of this information about a given company, it is difficult to appraise the legitimacy of this reason for withholding disclosure. On the positive side, it may be mentioned that some leading companies with diversified product lines-for example, International Harvester and FMC Corporation-do reveal a breakdown of dollar sales by major product categories although not the amount of net income derived from each.

\section{IV}

\section{Tax Regulations and Accounting Procedures}

The principle that statutory law and regulations thereunder pertaining to the computation of corporate taxable income should not necessarily determine the computation of net income reported to shareholders has been clearly stated in the AICPA's Research Bulletin No. 43 as follows: "Sound financial accounting procedures do not necessarily coincide with the rules as to what shall be included in 'gross income' or allowed as a deduction therefrom, in arriving at taxable net income." Unfortunately the language of this statement, like others found in the research bulletin guidelines, is permissive rather than strongly positive, possibly because it might be difficult to obtain consensus approval of a strong statement. Therefore, some companies, so far as can be determined from an analysis of their annual reports, have departed from the recommended principle and have allowed the tax rules to control the determination of important expenses on the income statement, whereas others have used conventional accounting concepts to determine expense allocations when the tax rules diverge from such concepts.

The latter approach unquestionably is preferable for investment analysis purposes because considerations other than the objective of determining net income in a rational and consistent manner affect the tax rules. For example, national economic policy objectives to stimulate capital investment and to encourage the expansion of productive capacities deemed essential to national security have been incorporated into various tax provisions. Moreover, the tax rules have been notoriously unstable in certain respects, as frequent amendments to the tax statutes and the related regulations have become customary in recent years. The result has been a deplorable morass of questionable reliability of many income statements, inconsistencies through time in expense determination methods, and lack of comparability between companies within the same industry.

The expense deductions for depreciation and amortization have probably been the main problem area. But others could be cited-for example, whether foreign earnings should be considered subject to the federal income tax in the year earned or when remitted to the parent company, as the tax rules allow deferment of payment until actual remission is made. However, because of their dominant and

\footnotetext{
${ }^{10}$ Committee on Accounting Procedure, AICPA, Restatenent and Revision of Accountino ReSEARCH BULletiNs 76 (Accounting Research Bull. No. 43, r953).
} 
TABLE 4

INLAND STEEL COMPANY

Analysis of Depreciation Charges: $1959-64$

(in millions of \$)

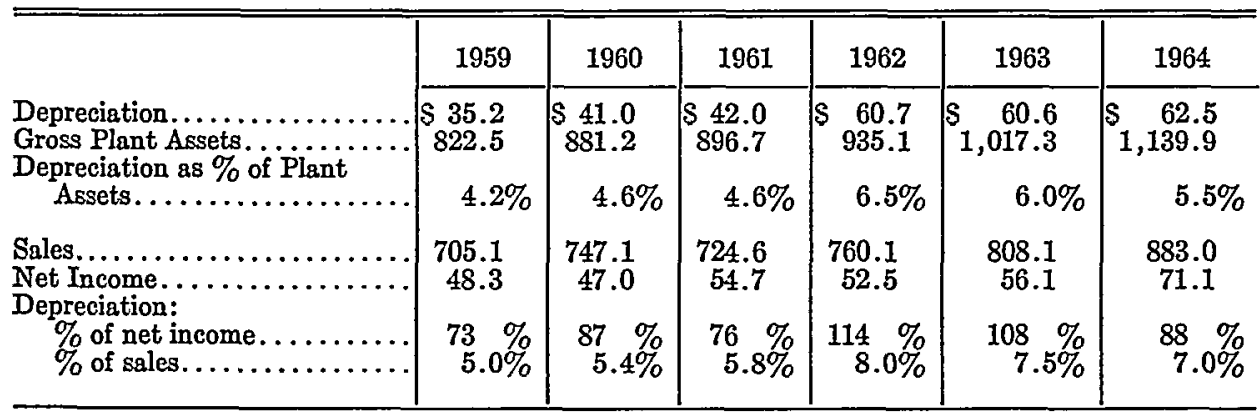

Source: Annual Reports for 1959-64.

general importance, the issues surrounding depreciation practices deserve special emphasis.

The major steel companies have been among those that have created considerable problems for investment analysts by allowing the tax rules to control the annual allowance for depreciation on their income statement supplied to shareholders. The consequent inconsistencies through time in the determination of this expense by these companies are suggested by the following statement by Inland Steel Company in its annual report for 1964 :

Prior to I962, Inland and its subsidiaries applied accelerated depreciation methods to property additions made since January I, 1954, as permitted by the 1954 Revenue Code. For additions made before 1954, depreciation charges were calculated on a straight-line basis or, on a sliding scale based on the rate of production. Depreciation charges for 1962,1963 , and 1964 , are based on the guidelines issued by the Treasury Department in 1962 , using accelerated depreciation methods for property additions made since January I, I954 and the straight-line method for assets acquired prior to $1954 \cdot{ }^{17}$

Moreover, it may be noted that in the mid-I950s when five-year amortization of a major portion of new facilities was permitted for national defense reasons, such amortization was also fully deducted as a normal operating expense on the income statements of Inland Steel.

The preposterous results ensuing from following the tax rules in determining depreciation charges are shown in table four. From the table it can be noted that the average annual depreciation deduction on the income statement for the 1962-64 period was about $\$ 6 \mathrm{r} .3$ million as compared to $\$ 39.4$ million in $1959-6 \mathrm{r}$, an increase of about 55 per cent. The increase in depreciation charges in the single year of $\mathrm{Ig} 62$ to $\$ 60.7$ million from $\$ 42$ million in $\mathrm{I} 96 \mathrm{r}$, or by 40 per cent, was particularly

\footnotetext{
${ }^{17}$ I964 INLAND Steel Co. ANn. Rep. 4.
} 
remarkable as during that year gross plant assets subject to depreciation charges increased by only 4.3 per cent. As a so-called "fixed expense" item in the short-run, depreciation charges would ordinarily be expected to decline as a percentage of sales as sales increase, but between 1959 and 1964 the data show that annual sales increased from $\$ 705$ million to $\$ 883$ million, or by about 25 per cent, yet depreciation as a percentage of sales also moved upward from 5 per cent to 7 per cent.

Whether depreciation rates were too low in $1959-6 \mathrm{r}$ or too high in $1962-64$ in relation to the effective useful lives of the plant assets could not be entirely determined. However, in its $\mathrm{r} 6_{3}$ annual report, Inland Steel offered the following statement:

It is encouraging that the Treasury Department through the guideline rules issued in 1962 , recognized that numerous and rapid changes in technology in recent years have shortened the average economic life of steel mill equipment. Certain of the guideline lives are still excessively long....

While this claim may be partially discounted as an attempt to secure more favorable tax treatment (which the stockholder might applaud), it represented at least some evidence that depreciation rates were excessively low prior to $I 962$ and that, as a consequence, true earnings were less than reported earnings in the earlier years.

But in any event the important fact was that reported earnings prior to 1962 were not comparable for trend analysis purposes with those reported subsequently because of a discretionary increase in depreciation rates engendered by changes in the tax rules. As a solution to the problem, it might be suggested that when material changes are made in the basis for the determination of financial statement items, companies should be required to supply supplementary information as to these items adjusted to current practices for perhaps four or five prior years.

However, in the specific instance considered above, such retroactive adjustments would still not make the earnings comparable with other companies that have adopted the procedures recommended in Research Bulletin No. 43. In essence, the recommendation here is that companies should determine depreciation rates via a conventional method without regard to the tax rules and preferably maintain reasonable consistency in this method through time. Then if the allowable depreciation charges for tax purposes exceed those deducted for statement purposes, a deferred tax reserve should be established to equalize the tax accruals over the write-off period. Because comparability and consistency of reported earnings is maintained under this procedure, it can be regarded as highly preferable for investment analysis purposes.

\section{$\mathrm{V}$}

The Interstate Commerce Commission and Accelerated Depreciation

The jurisdiction of the Interstate Commerce Commission over the accounting practices of the railroads led many years ago to the prescription of a uniform system 
of accounts to be followed by all railroads in reporting to the ICC. For financial analysis purposes, some of the results were highly salutary. First, the railroads were required to disclose considerable detail with respect to their financial and physical operations. Second, the analyst obtained exact comparability in these data among all railroads. A major drawback, however, has emerged in recent years that can only be characterized as a lack of flexibility to adjust the accounting regulations to changes in the institutional factors bearing on appropriate accounting procedures, notably in the taxation area. For example, in 1956 the Commission denied a petition to modify the uniform system of accounts to require that provision be made for federal income taxes deferred as a result of deducting accelerated amortization of certain facilities for tax purposes but not on the statements submitted to stockholders. ${ }^{18}$

But finally, in 1962 , the ICC issued an order that in substance permitted, but did not require, that financial statements submitted in annual reports could be prepared "in conformity with generally accepted accounting principles for which there is authoritative support" provided variances from the prescribed procedures were disclosed.19 Unfortunately, however, many if not most of the railroads have not yet taken advantage of this permissive order, and the result has been a serious overstatement of reported earnings in many cases. The overstatement results from the fact that plant facilities are being amortized more rapidly for tax purposes than on the published income statements, yet no provision is made for deferred tax liability that is clearly consequential to such a procedure. Most railroads have apparently taken the position that until the need for the deferred tax accrual is recognized in the uniform system of accounts, it will not be incorporated in their formal statements submitted to shareholders. ${ }^{20}$

For example, table five shows selected items from the consolidated income statements of the Atchison, Topeka \& Santa Fe Railway Company, for the years 1961-64, and also the estimated annual provision for deferred taxes computed from information supplied in the body of the report to stockholders for each year. This information, it should be emphasized, was not referred to or shown in the financial statements themselves. Moreover, the explanations were phrased in rather technical language, which the ordinary investor would find quite difficult to understand. A

\footnotetext{
${ }^{18}$ Interstate Commerce Commission Jurisdiction Over Financial Statements in Reports to Stockholders, in 7 Arthur Andersen \& Co., Cases in Public Accounting Practice 4 (I962).

${ }^{10} \mathrm{Id}$. at 9 .

${ }^{20}$ The following statement illustrates the policy of a major railroad in this regard: "Each Annual Report since r95I has explained the variances in earnings that result because income statements to the Interstate Commerce Commission, and as shown in this report, do not correspond with the manner in which the reporting is made to the Internal Revenue Service for tax purposes." 1964 Atchison, Topeka \& Santa Fe RY. AnN. Rep. 4. The statement suggests that the company, despite the I 962 permissive order from the ICC, intends to continue to report to stockholders in accord with the uniform system of accounts.
} 
TABLE 5

Atchison, Topera \& Santa Fe Railway Company

Adjustment for Deferred Taxes Resulting from Accelerated Depreciation

(in millions of \$)

\begin{tabular}{|c|c|c|c|c|}
\hline Per Statement: & 1961 & 1962 & 1963 & 1064 \\
\hline 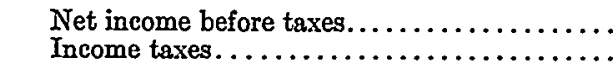 & $\$ 92.1$ & $\begin{array}{r}\$ 87.6 \\
14.2\end{array}$ & $\begin{array}{r}\$ 82.5 \\
11.2\end{array}$ & $\begin{array}{r}888.7 \\
8.0\end{array}$ \\
\hline $\begin{array}{l}\text { Reported net income................... } \\
\text { Supplementary information: } \\
\text { Estimated tax adjustments (net). }\end{array}$ & $\begin{array}{r}\$ 56.3 \\
6.2\end{array}$ & $\begin{array}{r}\$ 73.4 \\
25.3\end{array}$ & $\begin{array}{r}\$ 71.3 \\
24.8\end{array}$ & $\begin{array}{r}\$ 80.7 \\
26.8\end{array}$ \\
\hline Net income adjusted... & $\$ 50.1$ & $\$ 48.1$ & $\$ 46.5$ & $\$ 53.0$ \\
\hline
\end{tabular}

Source: Annual Reports for 1961-64.

thorough professional analyst, however, should have been able to make the indicated adjustments without great difficulty.

But to allow, if not encourage, the preparation of income statements on a basis that permits a gross overstatement of reported net income plus a probably erratic and noncomparable flow of such income through time seems open to serious criticism. Therefore, unless the uniform system of accounts prescribed by the ICC becomes more responsible to new institutional conditions, particularly in the taxation area, it can only be concluded that the ICC regulation of accounting practices has operated to the serious disadvantage of investors. In fact, the current procedure in determining the effective tax liability incident to periodic income is so flagrantly misleading that it might conceivably support a charge of substantive deception.

\section{VI}

\section{The "Investment Credit" Dilemma}

Presumably in order to stimulate an increase in business expenditures for plant and equipment, the Revenue Act of 1962 provided for an "investment credit" deduction from currently payable income taxes equal to specified percentages of certain depreciable assets acquired after $196 \mathrm{r}^{21}$ The 1962 statute provided that the amount of the credit must be deducted from the cost basis of the facilities subject to subsequent depreciation for tax purposes, but in 1964 the statute was amended to eliminate the requirement that the investment credit be deducted from the cost basis of eligible properties. ${ }^{22}$

The Accounting Principles Board of the AICPA originally held that the investment credit should be interpreted as "a reduction in or offset against a cost otherwise chargeable in a greater amount to future accounting periods" and that, as a result,

\footnotetext{
${ }^{21}$ INT. REv. CODE of 1954, $\$ 38,46-48$, added by Revenue Act of 1962, $\$$ 2(a)-(b), 76 Stat, 962 .

${ }^{22}$ INT. REv. CODE OF I954, $\$ 48(\mathrm{~g})$, repealed by Revenue Act of $1964, \$ 203(\mathrm{a}), 78$ Stat. 33 .
} 
"the allowable investment credit should be reflected in net income over the productive life of acquired property and not in the year in which it is placed in service."23 But in 1964 the APB modified its position to hold that while the same treatment "should be considered to be preferable, the alternative method of treating the credit as a reduction of federal income taxes of the year in which the credit arises is also acceptable."24 Therefore, in full accord with authoritative statements on appropriate accounting principles, companies may follow quite different methods of treating the investment credit with the result that comparability of earnings amounts, trends, and rates of return both within and between companies may be seriously impaired. The problem appears particularly acute in those industries that tend to acquire large blocs of eligible assets in given years and little if any such assets in other years. The reason is that those companies following the practice of deducting the entire investment credit from taxes in the year in which the assets are acquired would have a large reduction in taxes in one year due to the credit and little such 'reductions in other years. As a result, substantial changes in the level of reported net income may arise solely due to the timing of equipment acquisitions and the consequent investment credits that become available.

For example, Pan American World Airways reported net income in the amount of $\$ 37.1$ million in 1964 as compared to $\$ 33.6$ million in $x 963$. However, in $x 964$ the company adopted the practice of reducing federal income taxes by the entire amount of the investment credit resulting from equipment acquisitions in that year, which increased earnings by $\$ 6$ million alone. ${ }^{25}$ In other words, if consistency had been maintained in the method of accounting for the investment credit, earnings would have declined in 1964 instead of showing a substantial growth as reported. If flight equipment acquisitions decline in 1965 , it would seem entirely possible for reported earnings after taxes to decline even though pre-tax earnings increase, because of the reduced availability of the investment credit. It should be evident that obtaining an insight into the real economic trends of a firm's activities may become considerably more difficult under these conditions. Moreover, reported earnings are not comparable between firms treating the investment credit in different ways or even between firms with different timing in their equipment acquisitions.

The Accounting Principles Board gave two reasons for modifying its position with respect to the appropriate treatment of the investment credit. ${ }^{26}$ The first was that, as modified in the I964 Revenue Act, the credit could be logically construed as a rebate of taxes applicable to the year in which eligible facilities are acquired. As

\footnotetext{
${ }^{33}$ Accounting Principles Board, AICPA, Accounting for the "Investment Credit" 2-3 (Opinion No. 2, 1962).

24 Accounting Principles Board, AicPA, Accounting for the "Investment Credit" 2 (Opinion No. 4, 1964) (amending Opinion No. 2).

${ }^{25} \mathrm{y}_{96}$ Pan Axierican World Airways Ann. Rep. 20.

${ }^{20}$ Accounting Principles Board, AICPA, Accounting for the "Investment Credit" 2 (Opinion No. 4,1964 ) (amending Opinion No. 2).
} 
this reason is based on one plausible interpretation of the actual nature of the transaction, it can only be questioned on the basis that, nonetheless, an alternative interpretation is preferable for analysis purposes. The second reason advanced, however, is open to a more fundamental type of criticism. It was that a "significant number" of companies, and also, most unfortunately, the SEC, did not adopt the original recommendation for the treatment of the investment credit. Therefore, because the opinion did not receive general acceptability, the Board felt obliged to modify its position. This type of reasoning has disturbing general implications. It suggests that a position on an accounting principle is not necessarily based on whether its logical structure is actually correct or not but depends only on whether, regardless of a principle's logical foundations, its general acceptance is effectively achieved in practice. Under this approach, it would seem that the Board's opinion on important principles may be based on an empirical review of what actually does exist in practice tather than what should exist as a consequence of conclusions derived from objective reasoning. Can one conclude that popularity rather than objective logic may determine the formulation of authoritative opinions on accounting principles and procedures?

\section{VII}

\section{Statements of Financial Position: Of Lesser Significance}

Attention has been concentrated on the accounting issues surrounding the determination of periodic net income because such income is the basic source of investment returns and economic values in most publicly held corporations. For investment analysis purposes, therefore, the statement of financial position (balance sheet) is of distinctly secondary importance in most cases. Exceptions might, of course, be noted, such as cases of companies in the process of liquidation or merger or perhaps more notably certain natural resource companies where estimated reserves of the particular resources may be of considerable importance in the determination of investment values.

In the typical corporation, statements of financial position are used in investment analyses in perhaps two principal functional ways. The first is largely negative in concept. It is to determine if the company may encounter temporary or permanent trouble because of excessive debt assumption or its equivalent. The second involves the use of the balance sheet as one element in measuring rates of return obtained on the total invested capital at the disposal of management or, alternatively, on the effective capital contributed to the enterprise by the shareholders (net worth).

Prevailing financial reporting procedures are adequate for the most part in achieving these objectives. The amounts of net worth and contractual liabilities on debt obligations are usually clearly disclosed and the final maturities, or their range, on long-term debt are indicated. Moreover, if certain liabilities are secured by a pledge of specific assets, the nature of the lien position is customarily indicated at 
least in general terms. Two issues, however, might be briefly mentioned in this respect. First, it is not customary in the statement, or in the footnotes thereto, to reveal compulsory or contingent sinking fund requirements under bond trust indentures or preferred stock contracts. Similarly, the detailed breakdown of serial maturities, if used on long-term debt, is not typically reported. As the timing and possible concentration of repayments on debt principal may be pertinent to a conclusion on the financial vulnerability of a company, this information would appear desirable. And, as a matter of fact, the stated position of the accounting profession holds that "whenever these stipulations are significant to an adequate interpretation of the financial statements they should be described in the face of the balance sheet or the notes thereto." ${ }^{32}$ Therefore, the failure to disclose these data may be ascribed to a lack of implementation of an avowed recommendation in practice rather than to the accounting profession's silence or equivocation on the point.

The second issue is with respect to accounting for obligations under long-term lease commitments. With regard to such obligations, it should first be mentioned that the established position of both the accounting profession and the SEC is that the contractual amounts of minimum annual lease payments, as distinguished from contingent amounts, should be disclosed together with "the period over which the outlays will be made." ${ }^{28}$ Therefore, the analysis issue is not with respect to disclosure. However, it might be suggested that because a large portion of lease rentals often are the functional equivalent of interest charges (a contractual payment for capital provided to acquire the leased facilities), the minimum contractual annual lease rental payments should be shown on the income statement under a general caption "Interest Charges and Contractual Lease Rentals" with the amounts in each category then shown separately thereunder. This recommendation is made because it is the general and appropriate practice of financial analysts to include a portion, if not all, of minimum annual lease rentals in the computation of "fixed charges" used to compute the "times fixed-charges earned" ratio. ${ }^{29}$ This ratio, it might be mentioned, is the principal quantitative measure of the investment quality of the debt obligations and the financial soundness of a company.

Apart from the form of disclosure, the remaining issue is whether a portion or all of the contractual long-term lease rentals should be capitalized at an appropriate rate and recognized as a liability in the statement of financial position matched by an equivalent recognition of the leased facilities in the property accounts. A research study, sponsored by the AICPA, concluded that rights to use leased properties are conceptually economic assets and that, to the extent that the assumption of contractual lease payments represents the acquisition of such rights, the present value

\footnotetext{
${ }^{27}$ Paul Grady, Inventory of Generaliy Accepted Accounting Principles for Business EnterPRIses 285 (AICPA Accounting Research Study No. 7, I965).

${ }^{28}$ Accounting Princtples Board, AICPA, Reporting of I,enses in Financial Statements of LESSEE 32 (Opinion No. 5, I964).

${ }^{20}$ Grafair, Dodd \& CotTle, op. cit. supra note $\mathrm{I}$, at 402-03.
} 
of such payments should receive appropriate recognition in the assets and liabilities. ${ }^{30}$ However, the official position of the accounting profession to date is that formal recognition in the statement of financial position of the value of leased properties, along with the related liability, should occur only if the lease contract is in substance an instalment purchase. ${ }^{31}$

In any event, it is clear that the accountants have oriented their discussion of the issue to theoretical legal or economic concepts. In contrast, investment analysis circles tend to debate the issue on the grounds of the need to achieve analytical comparability between different firms in the same industry, some of which lease a large portion of their facilities while others own them outright. One view is that "no - valid comparison can be made between the bonds of the owning and those of the renting enterprises without a capitalization of all or some portion of the rentals paid."32 The other view, held by the author, is that the basic determination of the relative and absolute investment qualities of bond issues and companies in general is obtained largely from an appraisal of the earnings protection afforded the contractual charges and not from balance sheet proportions of debt to equity. Therefore, elaborate techniques to establish such effective proportions are of dubious significance in reaching investment decisions. Moreover, the legal remedies for a default on lease payments are considerably different from those for a default on debt, so the view that capitalized lease rentals essentially represent a debt obligation seems to be of questionable validity. For these reasons, it is concluded that a recognition of a balance sheet liability implicit in lease contracts is not of major importance for investment analysis purposes.

\section{VIII}

\section{Conclusions}

The foregoing discussion has been largely concerned with certain specific issues in accounting principles and procedures that affect the usefulness of accounting data in appraising the quality and values of corporate securities. Therefore, it might be well to conclude by setting forth some broad guidelines that, if adopted generally in the preparation of accounting reports, would greatly improve their reliability and consistency and the comparability of financial statements generally. Along these lines, Professor Herbert E. Miller, a leading academic accountant, has suggested several basic guidelines for accounting principles that, if adopted, would undoubtedly make financial reports more useful and intelligible to investors. In summary, his points may be listed as follows. ${ }^{33}$

\footnotetext{
${ }^{30}$ John H. Myers, Reporting of Leases in Financial Statements 38 (AICPA Accounting Rescarch Study No. 4, 1962).

${ }^{31}$ Accounting Principles Bonrd, aicPa, Reporting of Leases in Financial Statements of LESSEE 32 (Opinion No. $5, x 964$ ).

${ }^{32}$ Grafind, Dodd \& Cotrue, op. cit. supra note $\mathrm{x}$, at $36 \mathrm{r}$.

${ }^{3 a}$ Miller, Audited Statements-Are They Really Management's?, J. Accountancy, Oct. 1964, p. 43.
} 
r. Financial statements should reflect an objective and impartial report on management's performance.

2. The accounting profession has the obligation to correct any deficiencies in financial statements that impair an objective evaluation of managerial performances.

3. Disclosure of the use of unusual accounting principles or procedures in technical footnotes to the statements should not be regarded as alleviating the responsibility of the public accountant for their use in statements which receive unqualified opinions.

4. The accounting profession should not tolerate or advocate an "either-or" position on alternative procedures because of some uncertainty concerning which alternative is best. It should make a single choice from among the alternatives, even though some practitioners might dissent from the choice, in the interests of improved consistency and comparability.

5. Management's freedom of action in choosing alternative accounting procedures that have a material effect on the reported results should be strictly limited, if not eliminated, as there is a natural inclination for management to select the alternative that will make its position appear most favorable.

6. The outside auditor and not management should be in full control of the "ground rules" for the preparation of financial statements. Improved consistency and comparability cannot be achieved under the basic presumption that financial statements are primarily the responsibility of management, subject merely to modifying constraints of law and accepted principles in certain respects but with alternatives open for choice in many areas.

It would be sanguine to expect that the above guidelines will receive general implementation within the foreseeable future. Nevertheless, they do provide a clear and unequivocal framework for the development of more useful accounting data. Therefore, financial analysts would be well advised to support vigorously the above recommendations. The result may be at least evolutionary improvements in accounting standards to provide more reliable, consistent, and comparable financial statements. 